Annals of Plant and Soil Research 23(3): 351-355 (2021)

https://doi.org/10.47815/apsr.2021.10083

\title{
Performance of gerbera varieties under naturally ventilated polyhouse
}

\author{
M. VIJAYALAXMI, A. MANOHAR RAO, P. SAIDAIAH AND K. SWATHI
}

Department of Horticulture, Agricultural College, PJTSAU, Hyderabad

Received: May, 2021: Revised accepted: July, 2021

\begin{abstract}
ABSRACT
An experiment was conducted to evaluate ten varieties of gerbera under polyhouse conditions in Hyderabad. Vegetative, flowering and flower characters varied significantly among the cultivars and variations in different growth parameters were prominent. Mean performance of the cultivars revealed that cv. Helix recorded maximum plant height, flower diameter, flower stalk diameter and ray florets. The same cultivar Helix also produced maximum number of suckers per plant, number of flowers per plant, Fresh weight of flower, dry weight of flower and possessed longest field life which was at par with cv. Goliath. The cv. Goliath found superior with respect to maximum chlorophyll content, minimum days required for commence of first-flower and days taken for 50\% flowering. Maximum disc diameter and number of leaves were produced by cv. balance. While cv. Savannah had significantly maximum leaf area and length of the flower stalk. However, the cv. 'Montenegro recorded least mean value in terms of plant height, number of leaves per plant, leaf length, leaf breadth, leaf area, number of suckers, chlorophyll content, flower diameter, flower stalk diameter, ray florets, disc diameter, number of flowers per plant and took maximum days for first flower opening, $50 \%$ flowering and which was late in inducing flowering had lesser duration of flowering. Cultivar Helix exerted best performance on various growth and flower characters along with the cultivars Goliath, Danaellen, Balance and Savannah.
\end{abstract}

Keywords: Gerbera, flower yield, polyhouse, flower characters, varieties

\section{INTRODUCTION}

Gerbera (GerberajamesoniBolus) is an attractive cut flower crop belonging to the Asteraceae family, which is largest family of flowering plants. It occupies a unique position in beauty and trade among cut flowers and has significant demand due to its multitude of colours. Variety in color has made this flowering plant attractive for use in garden decorations, such as herbaceous borders, bedding, pots, rock gardens and for cut flowers as it has a long vase life. Besides this, performance of each cultivar varies with the region, season and other growing conditions. Considering the commercial importance of this crop, there is a prime need for identification of suitable cultivars for specific regions. Hence, the present study is being conducted to identify the suitable gerbera cultivars under protected conditions with respect to flower yield, quality and its important traits for plains of Telangana.Hence, the present investigation was planned with the objective to evaluate the performance of gerbera varieties under rain shelter in respect of growth, flowering and yield to explore the possibilities of identifying suitable varieties for commercial cultivation.

\section{MATERIAL AND METHODS}

The present investigation was carried out at Horticulture Garden, College of Horticulture, SKLTSHU, Hyderabad during 2015-16 and 2016-17. The experiment consisted of ten cultivars of gerbera viz., Balance, Stanza, Savannah, Dana Ellen, Goliath, Primerose, Helix, Liberty, Sabrina and Montenegro were bought from Kumar Florist (KF Bio plants), Pune. The genotypes were evaluated in randomized block design replicated three times. Raised beds of $30 \mathrm{~cm}$ height $70 \mathrm{~cm}$ width and 16 meter long were prepared inside a naturally ventilated poly house of 500sq.m (30mX20m.). Recommended dose of neem cake, FYM were applied at the time of planting. Tissue cultured plants of above mentioned varieties were planted on $2^{\text {nd }}$ January 2014 at a spacing of $30 \times 30 \mathrm{~cm}$ in two rows in each bed. The observations for vegetative parameters such as the plant height, number of leaves, leaf length and leaf breadth andnumber of suckers were recorded. Leaf area was measured by using Leaf area meter and chlorophyll content by SPAD meter. The floral parameters including number of flowers, numbers of the first appearing flowers till the last flowers to open, by continual removing the 
flowers as and when it opened were recorded. Flower stalk length,flower stalk diameter, flower diameter, total number of ray florets in each flower,fresh weigh and dry weight of flowers were recorded. Longevity of flower was recorded in a tagged plants from the day it opened to the day it end its life. Flowers were harvested early in the morning when two rows of disc florets were fully opened and perpendicular to the stalk. It was harvested with sideward push of the flower stem at the base. The harvested flowers were immediately placed in clean water to remove field heat. The data obtained were analyzed statistically and the significance level among the treatments was compared at 5 per cent of probability.

\section{RESULTS AND DISCUSSION}

\section{Vegetative Growth Parameters}

The data on theplant height showed significant differences among genotypes (Table 1). Plant height was maximum in cultivar 'Helix' $(45.5 \mathrm{~cm})$ and the next superior cultivars were Balance $(41.2 \mathrm{~cm})$ and Stanza $(41.0 \mathrm{~cm})$ and both were at par while $\mathrm{cv}$. Montenegro being the short stature recorded minimum plant height $(27.8 \mathrm{~cm})$. Intermediate plant height was recorded in cv. Savannah and cv. Danaellen (39.1 and 38.9, respectively). The plant height being genetically factored, it is expected to vary among the cultivars. The marked variation in the plant height may be due to varietal characters. Similar findings observed in Singh et al., (2017).

Gerbera cultivars showed significant variation for number of leaves per plant (Table 1). The cv. Balance exhibited more number of leaves per plant (50.2). Maximum leaf length and width were found from cv. Savannah $(26.3 \mathrm{~cm}$ and $13.4 \mathrm{~cm}$, respectively) which were on par with cv. Balance and number of leaves, leaf length and leaf breadth were minimum in cv. Montenegro $(22.0,19.4$ and 9.9, respectively).Wankhede and Gajbhiye (2013) suggested that variation in leaf production per plant among the varieties might be due to varietal characters. Variation in leaf production per plant has also been reported by Headuet al., (2012).Higher leaf area and Leaf area index were found in cv. Savannah $\left(197.9 \mathrm{~cm}^{2}\right.$ and $0.219)$ followed by cv. Stanza $\left(188.2 \mathrm{~cm}^{2}\right.$ and $0.209)$ and cv. Danaellen $\left(181.2 \mathrm{~cm}^{2}\right.$ and 0.201$)$ while least being in cv. Montenegro $\left(123.9 \mathrm{~cm}^{2}\right.$ and 0.138). Large sized and higher number of leaves gives higher leaf area. Maximum leaf area increased the photosynthetic efficiency of leaf surface leading to increased production of flowers. Variation in leaf area indicates additive gene effects would be effective in gerbera. The results were in accordance with the findings of Headuet al., (2012).

Table 1: Vegetative growth characters of gerbera cultivars

\begin{tabular}{|c|c|c|c|c|c|c|c|c|}
\hline Cultivar & $\begin{array}{c}\text { Plant height } \\
(\mathrm{cm})\end{array}$ & $\begin{array}{c}\text { Leaves/ } \\
\text { plant }\end{array}$ & $\begin{array}{c}\text { Leaf length } \\
(\mathrm{cm})\end{array}$ & $\begin{array}{c}\text { Leaf breadth } \\
(\mathrm{cm})\end{array}$ & $\begin{array}{c}\text { Leaf } \\
\text { Area }\end{array}$ & $\begin{array}{c}\text { Leaf Area } \\
\text { Index }\end{array}$ & $\begin{array}{c}\text { Suckers / } \\
\text { plant }\end{array}$ & $\begin{array}{c}\text { Chlorophyll } \\
\text { content }\end{array}$ \\
Helix & 45.5 & 32.5 & 25.1 & 12.9 & 166.2 & 0.185 & 7.9 & 64.2 \\
Sabrina & 34.3 & 33.7 & 21.1 & 10.6 & 126.2 & 0.140 & 5.3 & 63.5 \\
Montenegro & 27.8 & 22.0 & 19.4 & 9.9 & 123.9 & 0.138 & 4.2 & 58.9 \\
Liberty & 32.1 & 34.0 & 22.3 & 10.5 & 148.3 & 0.165 & 6.4 & 60.8 \\
Primerose & 33.6 & 27.4 & 19.9 & 9.3 & 132.9 & 0.148 & 7.0 & 59.4 \\
Savannah & 39.1 & 34.6 & 26.3 & 13.4 & 197.9 & 0.219 & 7.1 & 65.0 \\
Goliath & 35.1 & 32.7 & 22.1 & 9.7 & 157.9 & 0.175 & 9.2 & 75.9 \\
Stanza & 41.0 & 47.8 & 25.7 & 14.9 & 188.2 & 0.209 & 6.2 & 70.3 \\
Danaellen & 38.9 & 42.1 & 24.1 & 12.1 & 181.2 & 0.201 & 9.0 & 70.7 \\
Balance & 41.2 & 50.2 & 26.3 & 12.8 & 176.2 & 0.196 & 7.2 & 64.1 \\
S.E.D & 1.88 & 1.74 & 0.97 & 0.74 & 4.34 & 0.00 & 0.7 & 2.5 \\
C.D.(0.05) & 5.60 & 5.17 & 2.90 & 2.21 & 12.91 & 0.01 & 2.1 & 7.3 \\
\hline
\end{tabular}

Propagation of cultivars in terms of suckers per plant per year produced by cultivar was found more in cv. Goliath (9.2) as compared to other cultivars which was found to be at par with the cultivars Danaellen, Helix and Balance
(9.0, 7.9, and 7.2, respectively). The same cultivar Goliath recorded significantly maximum leaf chlorophyll content (75.9) which was found to be at par with the other cultivars Danaellen and Stanza (70.7 and 70.3). Whereas, cv. 
Montenegro exhibited poor suckering habit (4.2) and minimum chlorophyll content (58.9). Higher chlorophyll content, which might have led to increased photosynthesis and increased carbohydrates. Chobe et al.,(2010) reported similar observations in gerbera varieties.

\section{Flowering characters}

The perusal of data (Table 2) revealed that flowering characters varied significantly among the cultivars. Cultivar Goliath recorded significantly earlier for first-flower opening and days taken for $50 \%$ flowering (66.3 and 78.1, respectively). Since early and late flowering characters are genetically controlled, cultivars might be chosen accordingly for getting prolonged flowering duration. Similar variation in first flower opening was reported in 10 cultivars of gerbera by Rajiv kumar(2013) and 50\% floweringin 12 cultivars of gerbera by Lagamannaet al.,(2015). However, the cv. Helix was also superior with maximum duration of flowering (266.1) followed by cv. Goliath and cv. Danaellen (264.3 and 262.5, respectively) while maximum days to first-flower opening, days taken for $50 \%$ flowering and minimum days for flower durability recorded by cv. Montenegro. Slow development of flower after initiation of buds and minimum days for flower durability were marked in cv. Montenegro. Goliath and Helix cultivars performed best in case of days to first-flower opening, Days taken for 50\% flowering and flower durability. Variation in flowering parameters viz., days to first-flower opening, days taken for $50 \%$ flowering and duration of flowering showed by different gerbera varieties might be due to variation in their genetic factor. Chobe et al., (2010) recorded similar findings in gerbera varieties.

Table 2: Flowering characters of gerbera cultivars

\begin{tabular}{l|c|c|c|c|}
\hline \multicolumn{1}{|c|}{ Cultivar } & $\begin{array}{c}\text { Days to first-flower } \\
\text { opening }\end{array}$ & $\begin{array}{c}\text { Days taken for 50\% } \\
\text { flowering }\end{array}$ & $\begin{array}{c}\text { Duration of } \\
\text { flowering }\end{array}$ & $\begin{array}{c}\text { Flower } \\
\text { Colour }\end{array}$ \\
\hline Helix & 68.0 & 82.5 & 266.1 & Purple \\
Sabrina & 76.3 & 88.0 & 240.7 & Yellow \\
Montenegro & 80.1 & 92.5 & 238.3 & Yellow \\
Liberty & 75.2 & 86.3 & 255.0 & Pink \\
Primerose & 79.3 & 89.7 & 244.7 & Pink \\
Savannah & 69.3 & 83.3 & 260.8 & Red \\
Goliath & 66.3 & 78.1 & 264.3 & Orange \\
Stanza & 74.0 & 86.3 & 250.2 & Red \\
Danaellen & 69.1 & 80.3 & 262.5 & Yellow \\
Balance & 71.3 & 85.2 & 258.6 & White \\
S.E.D & 0.68 & 0.97 & 1.88 & \\
C.D.(0.05) & 2.04 & 2.88 & 5.59 & \\
\hline
\end{tabular}

\section{Flower quality characters}

Flower diameter was maximum in $\mathrm{cv}$. Helix $(13.5 \mathrm{~cm})$ followed by cv. Balance $(11.4 \mathrm{~cm})$. Whereas minimum flower diameter was recorded in cv. Montenegro (8.6). Similar variation in flower diameter has also been reported in gerbera by Kumar et al.,(2013). Stalk diameter varied significantly among the genotypes and cultivars Helix and Goliath recorded more stalk diameter $(7.7$ and $6.8 \mathrm{~cm}$, respectively) while in $\mathrm{cv}$. Montenegro was significantly lower than all the others $(4.9 \mathrm{~cm})$ as reported by Baruaet al., (2012) and Rajiv Kumar et al., (2012). Longest stalk was produced in cv. Savannah $(60.2 \mathrm{~cm})$ followed by $\mathrm{cv}$. balance
$(54.4 \mathrm{~cm})$. While the shortest was found from cv. Sabrina (38.2). The stalk length is a genetic factor therefore; it is expected to vary among the cultivars. As there will be more stalk length more reserved food will be stored in the stalk which will later be available to the flower for longer time period. The findings are in accordance with the result reported byManaswita Sil et al., (2017).

Number of ray florets ranged from 176.0 (Helix) to 62.9 (Montenegro). Significantly highest number was registered in cv. Helix (176.0), which was statistically and significantly superior over other genotypes. While cv. Montenegro (62.9) recorded lowest number of ray florets. Intermediate cultivars were Liberty, Sabrina and Goliath (124.3, 121.0 and 85.0 
respectively). Maximum diameter of disc was recorded in $\mathrm{cv}$. Balance $(2.6 \mathrm{~cm})$, which was at par with cultivars Helix $(2.4 \mathrm{~cm})$, Goliath $(2.3 \mathrm{~cm})$, Stanza $(2.3 \mathrm{~cm})$ and Danaellen $(2.2 \mathrm{~cm})$. Whereas it was recorded minimum in cv. Montenegro $(1.6 \mathrm{~cm})$ which was at par with cultivars Sabrina $(1.7 \mathrm{~cm})$ and Savannah
$(1.7 \mathrm{~cm})$. These differences in cut flower quality parameters of gerbera might be due to the inherent characters of the individual cultivars. The similar differences in gerbera have also been reported by Manaswita Silet al., (2017) and Biswalet al., (2017).

Table 3: Flower characters of gerbera cultivars

\begin{tabular}{l|c|c|c|c|c|c|c|c|c|}
\hline Cultivar & $\begin{array}{c}\text { Flower } \\
\text { diameter } \\
(\mathrm{cm})\end{array}$ & $\begin{array}{c}\text { Flower Stalk } \\
\text { diameter } \\
(\mathrm{cm})\end{array}$ & $\begin{array}{c}\text { Length of } \\
\text { the flower } \\
\text { stalk }\end{array}$ & $\begin{array}{c}\text { Ray } \\
\text { florets }\end{array}$ & $\begin{array}{c}\text { Disc } \\
\text { diameter } \\
(\mathrm{cm})\end{array}$ & $\begin{array}{c}\text { Field } \\
\text { life }\end{array}$ & $\begin{array}{c}\text { Number of } \\
\text { flowers / } \\
\text { plants }\end{array}$ & $\begin{array}{c}\text { Fresh } \\
\text { weight of } \\
\text { flower }\end{array}$ & $\begin{array}{c}\text { Dry } \\
\text { weight of } \\
\text { flower }\end{array}$ \\
\hline Helix & 13.5 & 7.7 & 47.0 & 176.2 & 2.4 & 12.5 & 32.8 & 17.8 & 3.0 \\
Sabrina & 9.0 & 5.1 & 38.2 & 121.0 & 1.7 & 8.8 & 21.8 & 12.2 & 1.5 \\
Montenegro & 8.6 & 4.9 & 39.4 & 62.9 & 1.6 & 9.4 & 16.0 & 12.7 & 1.6 \\
Liberty & 9.9 & 6.2 & 40.0 & 124.3 & 2.1 & 9.9 & 27.2 & 16.9 & 2.9 \\
Primerose & 9.5 & 5.3 & 44.3 & 68.2 & 1.9 & 10.5 & 22.1 & 13.4 & 2.0 \\
Savannah & 10.4 & 5.9 & 60.2 & 62.2 & 1.7 & 12.0 & 28.3 & 17.6 & 2.9 \\
Goliath & 10.7 & 6.8 & 50.5 & 85.0 & 2.3 & 14.2 & 32.4 & 18.3 & 3.4 \\
Stanza & 10.2 & 5.6 & 48.9 & 75.1 & 2.3 & 11.1 & 26.1 & 15.7 & 2.4 \\
Danaellen & 10.4 & 5.9 & 50.2 & 63.4 & 2.2 & 13.2 & 30.6 & 16.9 & 2.9 \\
Balance & 11.4 & 5.6 & 54.4 & 71.7 & 2.6 & 12.4 & 27.5 & 16.9 & 2.9 \\
S.E.D & 0.46 & 0.32 & 1.67 & 3.88 & 0.15 & 0.77 & 1.20 & 0.53 & 0.21 \\
C.D.(0.05) & 1.37 & 0.97 & 4.98 & 11.53 & 0.44 & 2.28 & 3.57 & 1.57 & 0.64 \\
\hline
\end{tabular}

Number of cut-flowers per plant varied from 16 to 38 flowers per plant per year.Significantly maximum yield was produced by cv. Helix (32.8) closely followed by cv. Goliath and cv.Danaellen (32.4 and 30.6, respectively) and cultivar Montenegro yielded the least number of flowers per plant (16.0). Such variation in flower yield was reported in gerbera by Singh et al., (2016). The differences in flower production among the cultivars might be due to temperature, prevailing in the region along with their genetic variability. Also, additive genes determine the productivity in gerbera plants. This was in accordance to the findings of Barooah and Talukdar (2009). The increase in flower yield may be attributed to the greater leaf area and more number of suckers and leaves per plant as well as plant spread which might have resulted in production and accumulation of maximum photosynthates, ultimately resulting the production in more number of flowers with bigger size.

With respect to field life of flower on plant, cv. Goliath exhibited longest field life (14.2 days) which was significantly superior over other varieties and at par amongst them and followed by cultivars Danaellen (13.2 days), Helix (12.5 days), Balance (12.4 days) and Savannah (12.0 days). However, cv. Sabrina recorded minimum field life (8.8 days) which is in accordance with the results of Wankhede and Gajbhiye (2013) in gerbera. The cv. Goliath recorded maximum fresh weight $(18.3 \mathrm{~g})$ which was found on par with cultivars Helix, Savannah, Danaellen, Balance, Liberty and Stanza (17.8, 17.6, 16.9, 16.9, 16.9 and $15.7 \mathrm{~g}$ respectively) whereas cv. Sabrina exhibited least weight $(12.6 \mathrm{~g})$. Similarly, it was observed that maximum dry weight was recorded in cv. Goliath $(3.4 \mathrm{~g})$ and it was at par with cultivars Helix, Danaellen, Savannah, Liberty and Balance (3.0, 2.9, 2.9, 2.9 and $2.9 \mathrm{~g}$ respectively). The minimum dry weight of flower was recorded in cv. Sabrina (1.5 g). Dry weight of flower is directly influenced by the fresh weight of flower thus show similar result as fresh weight of flower. This might be due to bigger size of flowers, more stalk length. The difference in quality character might be due to inherent characters of the individual cultivars and presence of additive genes.

It is concluded that the cultivars Helix and Goliath were found to be the promising cultivars. With respect to parameters viz., plant height, duration of flowering, flower diameter, Flower stalk diameter, Ray florets and number of flowers per plant were recorded maximum in cv. Helix. 
Whereas cultivar Goliath was also superior with rest of the characters, recorded maximum in number of suckers per plant, chlorophyll content, days to first flower opening, days to $50 \%$ flowering, field life, number of flowers per plant,

\section{REFERENCES}

Barua, U and Bordoli, R. (2012) Performance of gerbera cultivars under low cost polyhouse. Progressive Horticulture. 44(1): 37-39.

Barooah, L and Talukdar, M.C. (2009) Evaluation of different (Gerberajamesonii Bolus ex Hooker F.) cultivars under agro climatic conditions of Jorhat, Assam Journal of Ornamental. Horticulture. 12(2): $106-110$.

Biswal, M, Palai, S. K, Chhuria, S and Sahu, P. (2017) Evaluation of Exotic Cultivars of Gerbera (Gerbera jamesonil.) under Naturally Ventilated Polyhouse in Western Odisha. Journal of Krishi Vigyan. 5(2): 70-76.

Chobe, R.R, Pachankar, P.B and Warade, S.D. (2010) Performance of different cultivars of gerbera under polyhouse condition. The Asian Journal of Horticulture. 5(2): 333-335.

Hedau, N. K, Singh, B and Mishra, P. (2012) Evaluation of gerbera genotypes under protected conditions. Progressive Horticulture. 44(2): 336-337.

Kumar, R, Ahmed, N, Sharma, O. C, Mahendiran, G and Lal S. (2013). Screening of gerbera (Gerbera jamesonii) cultivars for quality, vase life and stem bending. Progressive Horticulture. 45: 2.

Lagamanna, R, Kullur, Balappa R, Devi Singh, Vivek Kumar and Digender Singh. (2015). Evaluation of recent varieties of gerbera for vegetative parameters grown under net house condition. Environment and Ecology. 33(2): 753-755. fresh weight and dry weight of flowers. Hence these two varieties are suitable for commercial cultivation under naturally ventilated polyhouse in agro-climatic conditions of Hyderabad, Telangana State.

Manaswita Sil, Madhumita Mitra Sarkar, Raghupathi, B and Mondal, S. (2017) Varietal Evaluation of Gerbera (Gerbera jamesonii.) Grown in a Polyhouse. International Journal of Current Microbiology and Applied Sciences.6 (7): 810-814.

Rajiv kumar, (2013) Evaluation of gerbera (Gerberajamesonii Bolus ex. Hooker F.) genotypesfor flower quality traits under naturally ventilated polyhouse. The AsianJournal of Horticulture. 8: 680-682.

Rajiv kumar, Bidyut, C and Deka, (2012) Evaluation of gerbera (Gerberajamesonii Bolus ex. Hooker F.) for vegetative and flowering characters under cost effective polyhouse. Progressive Agriculture. 12(1): $180-185$.

Singh, M. K, Sindhu, S. S and Kumar, S. (2016). Evaluation of Gerbera (Gerberajamesonii Bolus Ex. Hooker F.) under polyhouse conditions in mid hills of western Himalayas. International Journal of Tropical Agriculture. 34: 3.

Singh, P, Bhardwaj, A, Kumar, R and Singh, D. (2017). Evaluation of Gerbera Varieties for Yield and Quality under Protected Environment Conditions in Bihar. International Journal of Current Microbiology and Applied Sciences .6(9): 112-116.

Wankhede, S and Gajbhiye, R.P. (2013). Evaluation of Gerbera Varieties for Growth and Flowering under Shadenet. International Journal of Horticulture. 3 (9): 42-45. 